\title{
Aquiflexum balticum gen. nov., sp. nov., a novel marine bacterium of the Cytophaga- Flavobacterium-Bacteroides group isolated from surface water of the central Baltic Sea
}

Correspondence Ingrid Brettar inb@gbf.de

\author{
Ingrid Brettar, ${ }^{1}$ Richard Christen ${ }^{2}$ and Manfred G. Höfle ${ }^{1}$
}

\author{
${ }^{1}$ GBF - German Research Centre for Biotechnology, Dept Environmental Microbiology, \\ Mascheroder Weg 1, D-38124 Braunschweig, Germany \\ ${ }^{2}$ UMR 6543 CNRS and Université de Nice Sophia Antipolis, Centre de Biochimie, Parc \\ Valrose, F06108 Nice cedex 2, France
}

The Cytophaga-Flavobacterium-Bacteroides (CFB) group of bacteria is considered to be of special relevance for aquatic environments. In marine and freshwater environments, a high abundance of CFB bacteria can occur, and the CFB bacteria are considered to be of high relevance for the degradation of organic matter, such as complex polysaccharides (Cottrell \& Kirchman, 2000; Höfle, 1982, 1992; Pinhassi et al., 1999). An isolate, $\mathrm{BA} 160^{\mathrm{T}}$, was obtained from surface water of the central Baltic Sea at the entrance of the Gulf of Finland during the decay of a phytoplankton bloom. CFB bacteria have been shown to be major degraders of organic matter derived from phytoplankton. The isolate can therefore be considered as a bacterium that contributes

Published online ahead of print on 1 July 2004 as DOI 10.1099/ ijs.0.63255-0.

Abbreviation: CFB, Cytophaga-Flavobacterium-Bacteroides.

The GenBank/EMBL/DDBJ accession number for the $16 \mathrm{~S}$ rRNA gene sequence of Aquiflexum balticum BA160' is AJ744861.

A phase-contrast micrograph of and a table giving details of API results for strain $\mathrm{BA} 160^{\top}$ are available as supplementary material in IJSEM Online. to the degradation of plankton blooms in an aquatic environment such as the Baltic Sea. Despite the relevance of the CFB group for aquatic environments, available information on the taxonomy of aquatic CFB bacteria and their biodegradation potential is still very limited.

A new genus, designated Aquiflexum gen. nov., is shown here to belong to the CFB group of bacteria, which is also referred to as the phylum 'Bacteroidetes' (Ludwig \& Klenk, 2001). The new genus can be assigned to the family 'Flexibacteraceae, which includes 13 other genera and is one of three families belonging to the class 'Sphingobacteria' (Ludwig \& Klenk, 2001).

Strain $\mathrm{BA} 160^{\mathrm{T}}$ was isolated during a cruise on board the RV Aranda in September 1998 from surface water $(5 \mathrm{~m}$, $15{ }^{\circ} \mathrm{C}, 6 \% \mathrm{~S}, \mathrm{pH} 8 \cdot 2$ ) from a site in the central Baltic Sea at the entrance of the Gulf of Finland (station LL12, $59 \cdot 2900^{\circ} \mathrm{N}, 22 \cdot 5398^{\circ} \mathrm{E}$ ). All details on environmental conditions, sampling and isolation procedures are given elsewhere (Brettar et al., 2002; Brettar \& Rheinheimer, 1992; Brettar \& Höfle, 1993; Höfle \& Brettar, 1995). Medium for isolation was ZoBell agar (Oppenheimer \& Zobell, 1952) 
with a reduced sea salt content of $1 \%$. The strain grew well on half-strength ZoBell agar and marine broth or agar (no.2216; Difco). Cultivation of the strain below $28^{\circ} \mathrm{C}$ is not recommended because pronounced lag phases ( $>1$ week) may occur.

The isolate was tested for a number of key characteristics using standard procedures (Gerhardt et al., 1994), such as $\mathrm{KOH}$ string test (Gram stain), cell size and morphology (phase-contrast microscopy), cytochrome oxidase and catalase $\left(3 \% \mathrm{H}_{2} \mathrm{O}_{2}\right)$. Furthermore, production of indole, growth on $0.5 \%$ yeast extract, nitrate reduction, and hydrolysis of aesculin, casein, tyrosine, starch, gelatin and DNA were tested. Chitinase, cellulase and pectinase activities were tested as described by Atlas (1993). The strain was also characterized by using the whole test spectrum of the identification systems API 50CHE, API 20NE and API ZYM (bioMérieux) and Biolog GN2 at $28^{\circ} \mathrm{C}$. Growth was assessed at 4, 10, 20, 25, 30, 37, 40 and $45^{\circ} \mathrm{C}$. Different salinities were tested: $0,0 \cdot 8,1 \cdot 5,3,6$ and $10 \% \mathrm{NaCl}$. Growth at different $\mathrm{pH}$ values was also tested $(\mathrm{pH} 7,9$ and 10). For these tests, we used half-strength marine broth (no. 2216; Difco), except for the salinity test for which halfstrength salt-free ZoBell medium was supplemented with the respective amount of $\mathrm{NaCl}$.

Ethanol extracts of cells grown at $30^{\circ} \mathrm{C}$ on half-strength marine agar were examined by spectroscopy to check for pigments and flexirubin, as outlined by Gosink et al. (1998). Briefly, cells were extracted in $95 \%$ ethanol, and spectral analysis was performed from 250 to $700 \mathrm{~nm}$ before and after alkalinization with $0 \cdot 1$ vol. of $0 \cdot 1 \mathrm{M} \mathrm{NaOH}$.

Genomic DNA was prepared from individual colonies as described by Moore et al. (1996). 16S rRNA genes were amplified by PCR (Mullis \& Faloona, 1987) and the PCR products were sequenced directly as described previously (Moore et al., 1999).

For phylogenetic analyses, related sequences were selected from a database of 92000 pre-aligned bacterial 16S rRNA gene sequences and according to a BLAST against the latest release from the EBI (European Bioinformatics Institute). In a first analysis, 105 sequences were selected according to the results of the BLAST query (100 sequences) and to previous analyses. The new sequences were automatically and then manually aligned against these already aligned sequences. Among these sequences, 40 that were from cultured bacteria (type species and type strains when available) were selected for the final analysis. Phylogenetic trees were then constructed using these different datasets of sequences and three different methods (BIONJ, maximumlikelihood and maximum-parsimony). For the neighbourjoining analysis, distance matrices were calculated using Kimura's two-parameter correction. BIONJ was run according to Gascuel (1997), and maximum-likelihood and maximum-parsimony were run from PHYLIP (Felsenstein, 1995); for more details, see http://bioinfo.unice.fr (section 'publication', document: 'Phylogeny_How'). Analyses made with or without domains with potential homoplasies yielded the same results. The phylogenetic trees were drawn using NJPLOT (Perrière \& Gouy, 1996). The topology shown (Fig. 1) is that of the bootstrap neighbour-joining analysis. Bootstrap values (expressed as percentages of 1000 replications) are shown only for those branches that were retrieved by all three methods. There is no scale bar with the tree because it is a bootstrap tree.

The DNA G + C content (mol\%) of the strain was determined using HPLC analysis of hydrolysed DNA according to Tamaoka \& Komagata (1984) and Mesbah et al. (1989).

For fatty acid analysis, the strains were grown on halfstrength marine agar (no. 2216; Difco) for $24 \mathrm{~h}$ at $28^{\circ} \mathrm{C}$. The fatty acid methyl esters were obtained from washed cells by saponification, methylation and extraction. Analysis by gas chromatography was controlled by MIS software (Microbial ID, Newark, DE, USA) and peaks were automatically integrated and identified by the Microbial Identification software package (Sasser, 1990).

Strain $\mathrm{BA} 160^{\mathrm{T}}$ was Gram-negative and formed slender, long rods of $0 \cdot 3-0.6 \mu \mathrm{m}$ in width and $1 \cdot 1-4 \cdot 8 \mu \mathrm{m}$ in length (Fig. S1, available as supplementary material in

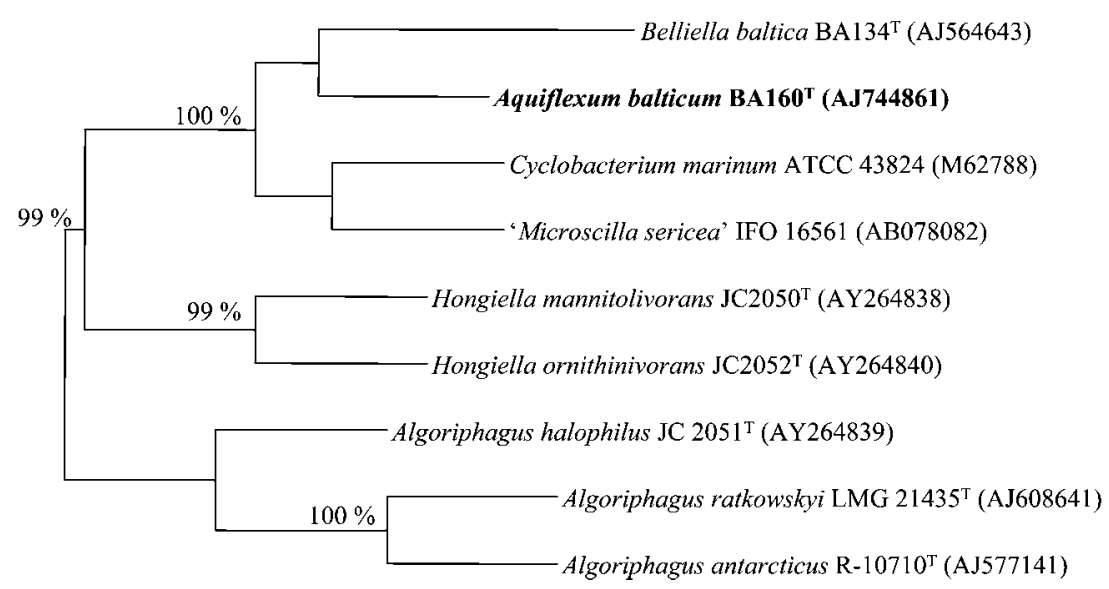

Fig. 1. Unrooted phylogenetic tree resulting from the analysis of nearly complete $16 \mathrm{~S}$ rRNA gene sequences. The species shown were chosen according to the results of a larger analysis. The topology shown was obtained using a neighbour-joining algorithm and 1000 bootstrap replications. Bootstrap values (expressed as percentages) are indicated only for branches found also by parsimony and maximum-likelihood $(P<0.01)$, and therefore define robust clusters. 
IJSEM Online). Occasionally, chains of up to five cells in length were observed. Gliding motility could not be observed by phase-contrast microscopy. Colonies were circular, smooth, transparent and bright red in colour on half-strength marine agar. With ongoing incubation, colonies became opaque. The strain was catalase-, cytochromoxidase- and aminopeptidase-positive. Growth was observed from 4 to $40^{\circ} \mathrm{C}$, with good growth between 10 and $35^{\circ} \mathrm{C}$, and optimum growth between 30 and $35^{\circ} \mathrm{C}$. Growth was observed at salinities from 0 to $6 \%$, with an optimum at $1.5 \%$. Growth occurred from $\mathrm{pH} 7$ to 9 , with an optimum around neutral conditions.

Strain $\mathrm{BA} 160^{\mathrm{T}}$ did not show a change in colour after alkalinization in the $\mathrm{KOH}$ string test (used as an indicator of Gram stain) nor after alkalinization of the ethanol extract of cells. The spectrum of the ethanol extract showed a broad peak with a maximum around $475 \mathrm{~nm}$ and two shoulder peaks at 450 and $505 \mathrm{~nm}$ - peaks that are typical for carotenoids. Alkalinization did not show a bathychromatic shift of the peaks. Therefore, we assume that strain $\mathrm{BA} 160^{\mathrm{T}}$ contained carotenoids but no flexirubins, as often observed for marine CFB bacteria (Reichenbach et al., 1981).

Strain $\mathrm{BA} 160^{\mathrm{T}}$ was able to reduce nitrate to nitrite and hydrolyse aesculin and starch. It did not produce indole, and did not degrade tyrosine or cellulose. It did not grow on agar supplemented with DNA, casein, chitin, pectin or $0.5 \%$ yeast extract.

In the API $50 \mathrm{CHE}$ test system, strain BA160 ${ }^{\mathrm{T}}$ showed acid production from 28 substrates (see species description). API $20 \mathrm{NE}$ test results indicated that six substrates were assimilated. The strain showed 12 enzymic activities. As a general rule, phenotypic features were rated positive when a signal was obtained, either weak or more pronounced (for details see Table S1, available as supplementary material in IJSEM Online).

In terms of its phenotypic features, strain $\mathrm{BA} 160^{\mathrm{T}}$ could be differentiated from the closely related species Cyclobacterium marinum (Raj \& Maloy, 1990) by cell morphology, salt dependence, salt tolerance, nitrate reduction, hydrolysis of starch and gelatin, and the ability to produce acid from three carbohydrates, to assimilate malate and to use eight carbonic acids (Table 1). It could be distinguished from Belliella baltica by the temperature range and optimum for growth, hydrolysis of gelatin, acid production from 13 substrates, assimilation of three substrates and utilization of seven substrates (Table 1). Compared to B. baltica, BA $160^{\mathrm{T}}$ showed a higher versatility concerning the use of organic substrates except for amino acids.

Phylogenetic analysis based on 16S rRNA gene sequence comparisons revealed that strain $\mathrm{BA} 160^{\mathrm{T}}$ formed a very robust clade (all methods, $100 \%$ of bootstrap replications) with Belliella, Cyclobacterium and Hongiella species while Algoriphagus species formed a closely related outgroup
(Fig. 1). Furthermore, strain BA160 ${ }^{\mathrm{T}}$ formed a robust clade with C. marinum and B. baltica, but could not be grouped robustly with any currently recognized species, suggesting that strain $\mathrm{BA} 160^{\mathrm{T}}$ should be recognized as representing a different genus. More extensive analyses including related sequences of described and undescribed bacteria demonstrated that strain $\mathrm{BA} 160^{\mathrm{T}}$ is located among a large set of sequences of undescribed bacteria.

The 16S rRNA gene sequence of strain $\mathrm{BA} 160^{\mathrm{T}}$ was most similar to those of $B$. baltica (GenBank/EMBL/DDBJ accession no. AJ564643, 92.4\% similar, 110 differences; Brettar et al., 2004), Hongiella ornithinivorans (AY264840, 92.3 \% similar, 114 differences; Yi \& Chun, 2004), Hongiella mannitolivorans (AY264838, 91.4\% similar, 118 differences; Yi \& Chun, 2004), Algoriphagus halophilus (AY264839, 90.6\% similar, 134 differences; Yi \& Chun, 2004; Nedashkovskaya et al., 2004), Algoriphagus ratkowskyi (AJ608641, 89.8\% similar, 147 differences; Bowman et al., 2003), Algoriphagus antarcticus (AJ577141, 90.2\% similar, 142 differences; Van Trappen et al., 2004) and C. marinum (M62788, 89.4\% similar, 155 differences; Raj \& Maloy 1990; Woese et al., 1990). The similarity of the $16 \mathrm{~S}$ rRNA gene sequence of strain $\mathrm{BA} 160^{\mathrm{T}}$ with that of C. marinum might be higher than the calculated value of $89.4 \%$, due to a number of non-determined nucleotides of the sequence of the latter.

The $\mathrm{G}+\mathrm{C}$ content of strain $\mathrm{BA} 160^{\mathrm{T}}$ was $38.4 \mathrm{~mol} \%$ (Table 1). The $\mathrm{G}+\mathrm{C}$ contents of $C$. marinum range from 34 to 38 mol\% (Raj \& Maloy, 1990; Gosink et al., 1998), while those of $B$. baltica range from $35 \cdot 3$ to $35 \cdot 5 \%$.

The cellular fatty acid composition of strain $\mathrm{BA} 160^{\mathrm{T}}$ showed a restricted spectrum of 17 fatty acids with a pronounced dominance of branched-chain $\mathrm{C}_{15}$ fatty acids. Abundant fatty acids were iso- $\mathrm{C}_{15: 0}(22 \cdot 6 \%)$, anteiso- $\mathrm{C}_{15: 0}(18 \cdot 6 \%)$, iso- $\mathrm{C}_{15: 0} \mathrm{G}(9 \cdot 4 \%)$ and iso- $\mathrm{C}_{16: 1} \mathrm{H}(9 \cdot 5 \%)$ (Table 2). The branched-chain fatty acids formed a fraction of at least $87 \%$, with iso-branching fatty acids forming the major fraction of $62 \%$. This calculation is based on the assumption that the detected double peak (ecl 15・19-15·48) represents $\mathrm{C}_{16: 1} \omega 7 c$, which cannot be differentiated by the MIDI system from iso- $\mathrm{C}_{15: 0} 2 \mathrm{OH}$. Otherwise, the fraction of isobranching fatty acids would be even higher. When compared with $B$. baltica, the number of fatty acid compounds detected in strain $\mathrm{BA} 160^{\mathrm{T}}$ is lower and the composition differs considerably. The major difference is the high abundance of anteiso- $\mathrm{C}_{15: 0}$ in strain $\mathrm{BA} 160^{\mathrm{T}}$ (B. baltica, $4 \cdot 5 \%$ ). A comparison of strain BA $160^{\mathrm{T}}$ with C. marinum $\mathrm{Raj}^{\mathrm{T}}$ (Urakami \& Komagata, 1986) showed for both a high fraction of iso- and anteiso- $\mathrm{C}_{15: 0}$ fatty acids, but contrasts with respect to the overall fatty acid composition ( $C$. marinum: iso- $\mathrm{C}_{15: 0} 44 \cdot 6 \%$; anteiso- $\mathrm{C}_{15: 0} 31 \cdot 5 \%$ ).

Of the currently recognized species, the Baltic Sea strain $\mathrm{BA} 160^{\mathrm{T}}$ is phylogenetically most closely related to $C$. marinum and B. baltica (Fig. 1). Due to the low level of 16S rRNA gene similarity and the lack of strong clustering 
Table 1. Features useful for distinguishing strain $B A 160^{\top}$ from closely related species

Species: 1, Aquiflexum balticum (strain $\mathrm{BA} 160^{\mathrm{T}}$ ); 2, Belliella baltica [data from Brettar et al. (2004), comprising strains BA1 and BA134 ${ }^{\mathrm{T}}$; 3, Cyclobacterium marinum [data from Raj \& Maloy (1990), comprising strains Raj $^{\mathrm{T}}$ (ATCC 25205 ${ }^{\mathrm{T}}$ ), WH-A (ATCC 43824) and WH-B (43825)]. Responses to substrates: +, good; W, weak; V, variable; -, no response; ND, no data available.

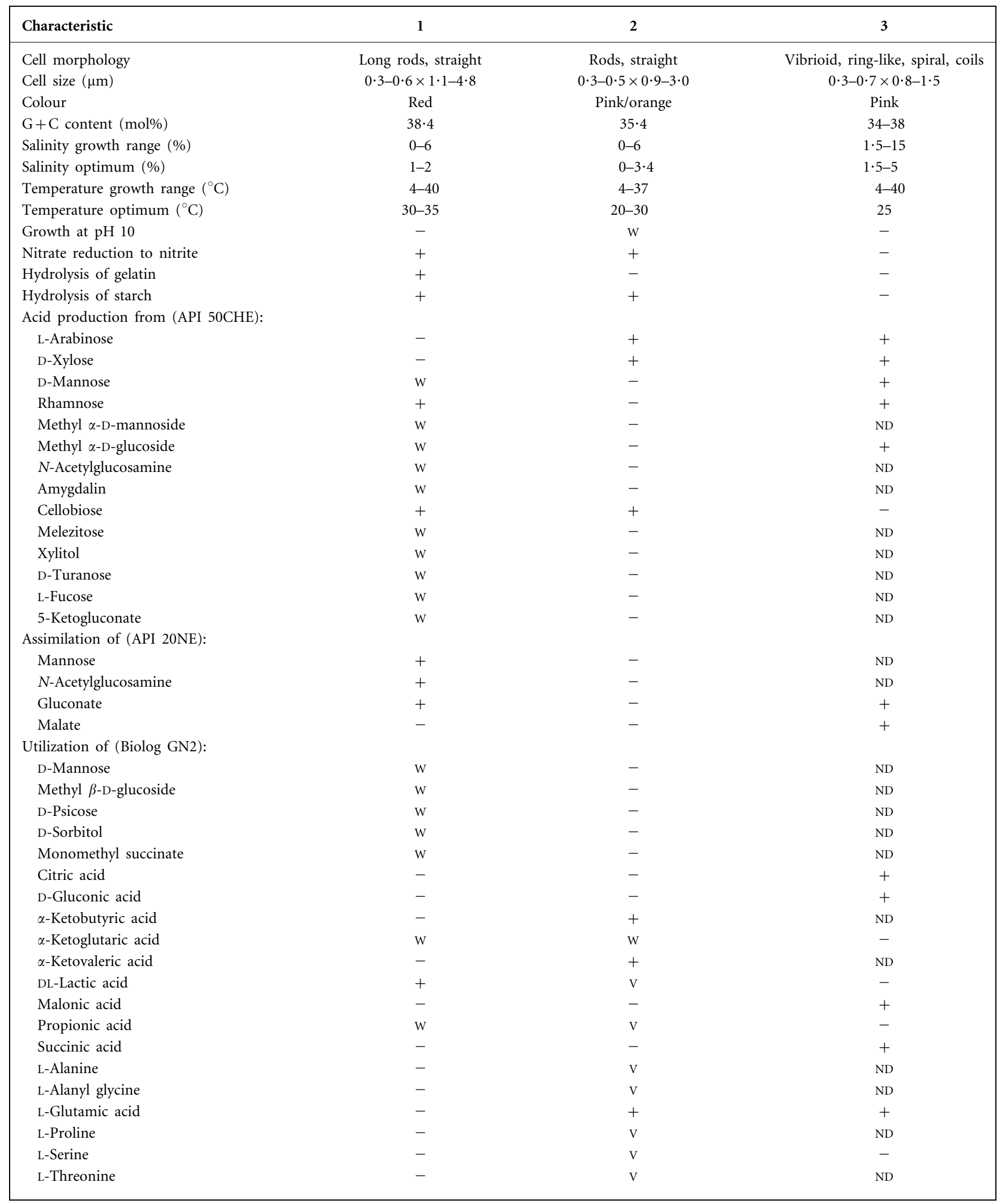


Table 2. Fatty acid composition of strain $B A 160^{\top}$ in comparison to $B$. baltica and C. marinum

Species: 1, A. balticum $\mathrm{BA} 160^{\mathrm{T}}$; 2, B. baltica [data from Brettar et al. (2004), comprising strains $\mathrm{BA} 1$ and $\mathrm{BA} 134^{\mathrm{T}}$ ]; 3, C. marinum (data from Urakami \& Komagata, 1986). Results are presented as a percentage of the total fatty acids; only those fatty acids contributing more than $1 \%$ are given. Fatty acids representing more than $5 \%$ are in bold. ND, Not detected.

\begin{tabular}{|c|c|c|c|}
\hline Fatty acid & 1 & 2 & 3 \\
\hline $\mathrm{C}_{13: 1}$ AT $12-13$ & ND & $<1 \cdot 44$ & \\
\hline iso- $\mathrm{C}_{14: 0}$ & $4 \cdot 77$ & $1 \cdot 98$ & \\
\hline $\mathrm{C}_{15: 0}$ & $\mathrm{ND}$ & $2 \cdot 94$ & $0 \cdot 2$ \\
\hline iso- $\mathrm{C}_{15: 0}$ & $22 \cdot 59$ & $20 \cdot 70$ & $44 \cdot 6$ \\
\hline anteiso- $\mathrm{C}_{15: 0}$ & $18 \cdot 53$ & $4 \cdot 53$ & $31 \cdot 5$ \\
\hline iso- $\mathrm{C}_{15: 0} 3 \mathrm{OH}$ & $1 \cdot 59$ & $2 \cdot 18$ & \\
\hline iso- $\mathrm{C}_{15: 1} \mathrm{G}$ & $9 \cdot 40$ & $10 \cdot 20$ & \\
\hline $\mathrm{C}_{15: 1} \omega 6 c$ & ND & $2 \cdot 07$ & \\
\hline iso- $\mathrm{C}_{16: 0}$ & $4 \cdot 23$ & $2 \cdot 64$ & \\
\hline $\mathrm{C}_{16: 0} 3 \mathrm{OH}$ & ND & $<1 \cdot 10$ & \\
\hline $\mathrm{C}_{16: 1}$ straight chain & & & $14 \cdot 2$ \\
\hline iso- $\mathrm{C}_{16: 1} \mathrm{H}$ & $9 \cdot 45$ & $3 \cdot 49$ & \\
\hline iso- $\mathrm{C}_{16: 1} 3 \mathrm{OH}$ & $2 \cdot 00$ & $1 \cdot 94$ & \\
\hline $\mathrm{C}_{16: 1} \omega 5 c$ & $1 \cdot 98$ & $3 \cdot 30$ & \\
\hline $\mathrm{C}_{16: 1} \omega 7 c /$ iso $-\mathrm{C}_{15: 0} 2 \mathrm{OH}^{*}$ & $6 \cdot 10$ & $9 \cdot 25$ & \\
\hline iso- $\mathrm{C}_{17: 0} 3 \mathrm{OH}$ & $1 \cdot 44$ & $3 \cdot 17$ & \\
\hline anteiso- $\mathrm{C}_{17: 1} \mathrm{~B}$ & $2 \cdot 55$ & $3 \cdot 69$ & \\
\hline $\mathrm{C}_{17: 1} \omega 6 c$ & $2 \cdot 99$ & $7 \cdot 28$ & \\
\hline $\mathrm{C}_{17: 1} \omega 8 c$ & $\mathrm{ND}$ & $1 \cdot 19$ & \\
\hline iso- $\mathrm{C}_{17: 1} \omega 9 c$ & $5 \cdot 22$ & $8 \cdot 38$ & \\
\hline anteiso- $\mathrm{C}_{17: 1} \omega 9 c$ & $1 \cdot 10$ & ND & \\
\hline $\mathrm{C}_{18: 1}$ straight chain & & & $8 \cdot 1$ \\
\hline iso- $\mathrm{C}_{19: 1} \mathrm{I}$ & $1 \cdot 46$ & ND & \\
\hline Not identified & $4 \cdot 60$ & $7 \cdot 70$ & \\
\hline
\end{tabular}

${ }^{\star}$ Not differentiated by the MIDI system.

by phylogeny, strain BA160 ${ }^{\mathrm{T}}$ was regarded as belonging to a new genus. The phylogenetic conclusions are supported by the fatty acid profile, cell morphology and physiological features of strain $\mathrm{BA} 160^{\mathrm{T}}$. Physiological features that differentiate strain $\mathrm{BA} 160^{\mathrm{T}}$ from $C$. marinum are the $\mathrm{NaCl}$ dependence for growth, the salinity range for growth, the reduction of nitrate and the spectrum of substrates utilized for growth and acid production; those that differentiate strain $\mathrm{BA} 160^{\mathrm{T}}$ from $B$. baltica are the temperature growth range and optimum, the $\mathrm{pH}$ range for growth and a rather distinct spectrum of substrates used for acid production and growth, showing a higher metabolic versatility for strain $\mathrm{BA} 160^{\mathrm{T}}$. Strain $\mathrm{BA} 160^{\mathrm{T}}$ was very distinct in terms of its cellular fatty acid composition. Based on this polyphasic study and its results for the novel Baltic Sea isolate, we propose a new genus, Aquiflexum gen. nov. Strain $B A 160^{\mathrm{T}}$ is proposed as the type strain of the novel species Aquiflexum balticum sp. nov.

\section{Description of Aquiflexum gen. nov.}

Aquiflexum (A.qui.flex'um. L. fem. n. aqua water; L. part. adj. flexus bent, winding; N.L. neut. n. Aquiflexum to indicate the bacterium's aquatic origin and its long flexible rods).

Cells are Gram-negative, rod-shaped and oxidase- and catalase-positive. Growth is heterotrophic and aerobic. Dominant fatty acids are of iso- $\mathrm{C}_{15: 0}$, anteiso- $\mathrm{C}_{15: 0}$, iso$\mathrm{C}_{15: 1} \mathrm{G}$ and iso- $\mathrm{C}_{16: 1} \mathrm{H}$. Cells contain carotenoids but no flexirubin. $\mathrm{NaCl}$ is not needed for growth, but growth is improved by its presence. The genus belongs to the phylum 'Bacteroidetes'.

The type species is Aquiflexum balticum.

\section{Description of Aquiflexum balticum sp. nov.}

Aquiflexum balticum (bal'ti.cum. N.L. neut. adj. balticum from the Baltic Sea, referring to the source of the type strain).

Colonies are circular, smooth, convex and entire. Red and transparent when young, but turn opaque with ongoing incubation ( $>1$ week, $30^{\circ} \mathrm{C}$, on half-strength marine agar). Cells are Gram-negative, rod-shaped (width, $0 \cdot 3-0 \cdot 6 \mu \mathrm{m}$; length, $1 \cdot 1-4 \cdot 8 \mu \mathrm{m}$ ), and oxidase- and catalase-positive. Reduces nitrate to nitrite. Temperature range for growth is $4-40{ }^{\circ} \mathrm{C}$, with an optimum around $30^{\circ} \mathrm{C}$. $\mathrm{NaCl}$ is not needed for growth, but growth occurs in the presence of 0 to $6 \% \mathrm{NaCl}$, with an optimum around $1.5 \%$. Grows from $\mathrm{pH} 7$ to 9 , with an optimum around neutral $\mathrm{pH}$. Does not grow on $0.5 \%$ yeast extract. Hydrolyses aesculin, starch and gelatin. Produces acid from galactose, D-glucose, D-fructose, D-mannose, rhamnose, methyl $\alpha$-D-mannoside, methyl $\alpha$-D-glucoside, $N$-acetylglucosamine, amygdalin, arbutin, aesculin, salicin, cellobiose, maltose, lactose, melibiose, sucrose, trehalose, inulin, melezitose, D-raffinose, amidon, glycogen, xylitol, $\beta$-gentobiose, D-turanose, $\mathrm{L}$-fucose and 5 -ketogluconate. Shows $\alpha$ - and $\beta$-glucosidase, $\beta$-galactosidase, acid and alkaline phosphatase, leucine, valine and cystine arylamidase, trypsin, chymotrypsin, naphtholphosphohydrolase and $N$-acetyl- $\beta$-glucosaminase activities. Assimilates glucose, arabinose, mannose, $\mathrm{N}$-acetylglucosamine, maltose and gluconate. Utilizes L-arabinose, cellobiose, L-fructose, D-galactose, gentobiose, $\alpha$-D-glucose, $\alpha$-D-lactose, lactulose, maltose, D-mannose, methyl $\beta$-Dglucoside, D-psicose, D-sorbitol, sucrose, D-trehalose, turanose, monomethyl succinate, acetic acid, $\alpha$-ketoglutaric acid, lactic acid and propionic acid as substrates. No use of amino acids is detected, but aminopeptidase is produced. Of marine or estuarine origin. The $\mathrm{G}+\mathrm{C}$ content is $38 \cdot 4 \mathrm{~mol} \%$.

The type strain is BA160 ${ }^{\mathrm{T}}\left(=\mathrm{DSM} 16537^{\mathrm{T}}=\mathrm{LMG} 22565^{\mathrm{T}}=\right.$ CIP $108445^{\mathrm{T}}$ ).

\section{Acknowledgements}

J. Bötel is acknowledged for excellent technical assistance. The support by the scientific and technical crew of the RV Aranda in September 
1998 is gratefully acknowledged. Special thanks to H. Kuosa and J. Kupparinen for support with sampling and the cruise. The analytical services of the DSMZ (Deutsche Sammlung von Mikroorganismen und Zellkulturen, Braunschweig, Germany) are gratefully acknowledged. Many thanks to S. Verbarg, R. M. Kroppenstedt and P. Schumann and their staff. Many thanks for the excellent support by A. Frühling. This work was supported by funds from the European Commission for the projects 'Marine Bacterial Genes and Isolates as Sources for novel Biotechnological Products' (MARGENES, MAS3-CT97-0125, MASTIII programme) and AQUA-CHIP (QLK4-2000-00764, Quality of Life and Management of Living Resources programme). The authors are solely responsible for the content of this publication. It does not represent the opinion of the European Commission. The European Commission is not responsible for any use that might be made of data appearing herein.

\section{References}

Atlas, R. M. (1993). Handbook of Microbiological Media. Edited by L. C. Parks. Boca Raton, FL: CRC Press.

Bowman, J. P., Mancuso Nichols, C. \& Gibson, J. A. E. (2003). Algoriphagus ratkowskyi gen. nov., sp. nov., Brumimicrobium glaciale gen. nov., sp. nov., Cryomorpha ignava gen. nov., sp. nov. and Crocinitomix catalasitica gen. nov., sp. nov., novel flavobacteria isolated from various polar habitats. Int J Syst Evol Microbiol 53, 1343-1355.

Brettar, I. \& Höfle, M. G. (1993). Nitrous oxide producing heterotrophic bacteria from the water column of the central Baltic: abundance and molecular identification. Mar Ecol Prog Ser 94, 253-265.

Brettar, I. \& Rheinheimer, G. (1992). Influence of carbon availability on denitrification in the water column of the central Baltic. Limnol Oceanogr 37, 1146-1163.

Brettar, I., Christen, R. \& Höfle, M. G. (2002). Rheinheimera baltica gen. nov., sp. nov., a blue-coloured bacterium isolated from the central Baltic Sea. Int J Syst Evol Microbiol 52, 1851-1857.

Brettar, I., Christen, R. \& Höfle, M. G. (2004). Belliella baltica gen. nov., sp. nov., a novel marine bacterium of the CytophagaFlavobacterium-Bacteroides group isolated from surface water of the central Baltic Sea. Int J Syst Evol Microbiol 54, 65-70.

Cottrell, M. T. \& Kirchman, D. L. (2000). Community composition of marine bacterioplankton determined by $16 \mathrm{~S}$ rRNA gene clone libraries and fluorescence in situ hybridization. Appl Environ Microbiol 66, 5116-5122.

Felsenstein, J. (1995). PHYLIP (phylogeny inference package), version 3.57c. Department of Genetics, University of Washington, Seattle, USA.

Gascuel, O. (1997). BIONJ: an improved version of the NJ algorithm based on a simple model of sequence data. Mol Biol Evol 14, 685-695.

Gerhardt, P., Murray, R. G. E., Wood, W. A. \& Krieg, N. R. (1994). Methods for General and Molecular Bacteriology. Washington, DC: American Society for Microbiology.

Gosink, J. J., Woese, C. R. \& Staley, J. T. (1998). Polaribacter gen. nov., with three new species, $P$. irgensii sp. nov., $P$. franzmannii sp. nov. and $P$. filamentus sp. nov., gas vacuolate polar marine bacteria of the Cytophaga-Flavobacterium-Bacteroides group and reclassification of 'Flectobacillus glomeratus' as Polaribacter glomeratus comb. nov. Int J Syst Bacteriol 48, 223-235.

Höfle, M. G. (1982). Glucose uptake of Cytophaga johnsonae studied in batch and chemostat culture. Arch Microbiol 133, 289-294.
Höfle, M. G. (1992). Bacterioplankton community structure and dynamics after large-scale release of nonindigenous bacteria as revealed by low-molecular-weight-RNA analysis. Appl Environ Microbiol 58, 3387-3394; erratum 59, 351.

Höfle, M. G. \& Brettar, I. (1995). Taxonomic diversity and metabolic activity of microbial communities in the water column of the central Baltic Sea. Limnol Oceanogr 40, 868-874.

Ludwig, W. \& Klenk, H.-P. (2001). Overview: a phylogenetic backbone and taxonomic framework for procaryotic systematics. In Bergey's Manual of Systematic Bacteriology, 2nd edn, vol. 1, pp. 49-65. Edited by D. R. Boone, R. W. Castenholz \& G. M. Garrity. New York: Springer.

Mesbah, M., Premachandran, U. \& Whitman, W. B. (1989). Precise measurement of the $\mathrm{G}+\mathrm{C}$ content of deoxyribonucleic acid by high-performance liquid chromatography. Int J Syst Bacteriol 39, 159-167.

Moore, E. R. B., Mau, M., Arnscheidt, A., Böttger, E. C., Hutson, R. A., Collins, M. D., Van De Peer, Y., De Wachter, R. \& Timmis, K. N. (1996). The determination and comparison of the 16S rRNA gene sequences of species of the genus Pseudomonas (sensu stricto) and estimation of the natural intrageneric relationships. Syst Appl Microbiol 19, 476-492.

Moore, E. R. B., Arnscheidt, A., Krüger, A., Strömpl, C. \& Mau, M. (1999). Simplified protocols for the preparation of genomic DNA from bacterial cultures. In Molecular Microbial Ecology Manual, 1.6.1, 1-15. Edited by A. D. L. Akkermans, J. D. van Elsas \& F. J. de Bruijn. Dordrecht, the Netherlands: Kluwer Academic Press.

Mullis, K. B. \& Faloona, F. A. (1987). Specific synthesis of DNA in vitro via a polymerase-catalyzed chain reaction. Methods Enzymol 155, 335-350.

Nedashkovskaya, O. I., Vancanneyt, M., Van Trappen, S. \& 7 other authors (2004). Description of Algoriphagus aquimarinus sp. nov., Algoriphagus chordae sp. nov. and Algoriphagus winogradskyi sp. nov., from sea water and algae, transfer of Hongiella halophila Yi and Chun 2004 to the genus Algoriphagus as Algoriphagus halophilus comb. nov. and emended descriptions of the genera Algoriphagus Bowman et al. 2003 and Hongiella Yi and Chun 2004. Int J Syst Evol Microbiol 54, 1757-1764.

Oppenheimer, C. H. \& ZoBell, C. E. (1952). The growth and viability of sixty-three species of marine bacteria as influenced by hydrostatic pressure. J Mar Res 11, 10-18.

Perrière, G. \& Gouy, M. (1996). WWW-query: an on-line retrieval system for biological sequence banks. Biochimie 78, 364-369.

Pinhassi, J., Azam, F., Hemphala, J., Long, R. A., Martinez, J., Zweifel, U. L. \& Hagström, A. (1999). Coupling between bacterioplankton species composition, population dynamics, and organic matter degradation. Aquat Microb Ecol 17, 13-26.

Raj, H. D. \& Maloy, S. R. (1990). Proposal of Cyclobacterium marinus gen. nov., comb. nov. for a marine bacterium previously assigned to the genus Flectobacillus. Int J Syst Bacteriol 40, 337-347.

Reichenbach, H., Kohl, W. \& Achenbach, H. (1981). The flexirubin pigments, chemosystematically useful compounds. In The Flavobacterium-Cytophaga Group, pp. 101-108. Edited by H. Reichenbach \& O. B. Weeks. Weinheim: Verlag Chemie.

Sasser, M. (1990). Identification of bacteria by the gas chromatography of cellular fatty acids. MIDI Technical Note 101. Newark: MIDI Inc.

Tamaoka, J. \& Komagata, K. (1984). Determination of DNA base composition by reversed-phase high-performance liquid chromatography. FEMS Microbiol Lett 25, 125-128.

Urakami, T. \& Komagata, K. (1986). Methanol-utilizing Ancylobacter strains and comparison of their cellular fatty acid compositions and 
quinone systems with those of Spirosoma, Flectobacillus, and Runella species. Int J Syst Bacteriol 36, 415-421.

Van Trappen, S., Vandecandelaere, I., Mergaert, J. \& Swings, J. (2004). Algoriphagus antarcticus sp. nov., a novel psychrophile from microbial mats in Antarctic lakes. Int J Syst Evol Microbiol 54, 1969-1973.
Woese, C. R., Maloy, S., Mandelco, L. \& Raj, H. D. (1990). Phylogenetic placement of the Sprirosomaceae. Syst Appl Microbiol 13, 19-23. Yi, H. \& Chun, J. (2004). Hongiella mannitolivorans gen. nov., sp. nov., Hongiella halophila sp. nov. and Hongiella ornithinivorans sp. nov., isolated from tidal flat sediment. Int J Syst Evol Microbiol 54, 157-162. 